\title{
The Power of Productivity: Wealth, Poverty, and the Threat to Global Stability.
}

William W. Lewis. Chicago: University of Chicago Press, 2004. 370 p. ISBN: 0226476766 .

por José Matias Pereira (PPGA/UnB)

A produtividade não provoca desemprego. O gerenciamento incompetente, a falta de método de produção e a desorganização empresarial prejudicam a sociedade mais do que se imagina. Estas são algumas das constatações contidas no livro de William W. Lewis O Poder da Produtividade: Riqueza, pobreza e a ameaça à estabilidade global. $O$ trabalho se apresenta como um estudo sério e instigante sobre os prejuízos provocados pela disparidade que existe entre países ricos e pobres. Esse fosso, para aquele autor, se apresenta como o problema mais sério e preocupante da atualidade no mundo.

Lewis aborda no seu estudo alguns temas sensíveis como: 1. Findings: The Global Economic Landscape; Part 1 - Rich and Middle-Income Countries; 2. Japan: A Dual Economy; 3. Europe: Falling Behind; 4. The United States: Consumer Is King; 5. Korea: Following Japans Path. Part 2 - Poor Countries; 6. Brazil: Big Government Is Big Problem; 7. Russia: Distorted Market Economy; 8. India: Bad Economic Management from Democratic Government. Part 3 - Causes and Implications; 9. Patterns: Clear and Strong; 10. Why Bad Economic Policy around the World?; 11. New Approaches; 12. So What? McKinsey Global Institute Reports. Recommended Readings.

O estudo iniciado pelo instituto global de McKinsey, tornou possível estudar a dinâmica e a evolução de um grupo representativo das indústrias em 13 países: Austrália, Brasil, França, Alemanha, Índia, Japão, os Países Baixos, a Polônia, a Rússia, Coréia do Sul, Suíça, o Reino Unido e os Estados Unidos. Em cada um desses países foram analisados os desempenhos de 6 a 13 indústrias e que foram comparados com o desempenho das mesmas indústrias em um conjunto de outros países. O trabalho foi baseado em estudos detalhados de negócios individuais. A pesquisa foi efetuada partir de uma bem testada metodologia, desenvolvida pela própria McKinsey e para cuja aplicação ela está particularmente bem habilitada, por ter um profundo conhecimento das atividades analisadas, não somente em suas características tecnológicas e organizacionais, mas também quanto às práticas empresariais nos principais países industriais. A soma da consistência do método utilizado na pesquisa do instituto global de McKinsey e a longa experiência de Lewis com as questões 
que envolvem política econômica colocam o poder da produtividade como um tema relevante na economia global.

Argumenta Lewis que a pobreza crônica de muitas nações afeta mais do que os cidadãos e as economias daquelas nações. Essa pobreza crônica é uma ameaça à estabilidade global enquanto as pressões de imigração se tornam insustentáveis e nações deterioradas procuram o poder e a influência através de política extrema e do terrorismo. Para resolver os problemas desta pobreza tenaz, observa Lewis, uma vasta gama de instituições internacionais canalizou bilhões de dólares para estas nações nas últimas décadas do século XX. Apesar desses investimentos e do esforço feito, cerca de cinco bilhões de pessoas (dos seis bilhões de pessoas que habitam o mundo) continuam a viver em países pobres.

Para Lewis a competição séria é geralmente uma condição necessária para melhorar técnicas. Esse tipo de competição, entretanto, é improvável de ocorrer sem uma definição nacional que concorde em priorizar os consumidores em detrimento aos produtores. A informalidade, definida como o não cumprimento de diferentes obrigações por parte dos agentes econômicos - evasão fiscal, a chamada economia paralela, o descumprimento das obrigações sociais -, foi identificado pelo McKinsey Global Institute (MGI) como a principal entrave ao desenvolvimento econômico nacional. Ela representa um significativo do diferencial global da produtividade identificado como passível de ser enfrentado e superado.

Registre-se que, o tema produtividade, por sua vez, não é um assunto recente no Brasil (MATIAS-PEREIRA, 2004). Destaca-se entre esses estudos o livro: Produtividade no Brasil: A Chave do Desenvolvimento Acelerado, publicado pela Editora Campus, em 1999. O citado trabalho, contendo artigos de vários economistas brasileiros, é resultado de estudos do próprio Instituto McKinsey sobre a produtividade empresarial no Brasil.

O trabalho de Lewis busca demonstrar que a chave para melhorar as condições econômicas em países pobres está no aumento da produtividade, por meio da competição intensa, justa e da aplicação dos direitos de proteção ao consumidor. Argumenta Lewis que para melhorar o bem-estar econômico dos indivíduos, os países devem aumentar sua produtividade, primeiramente incentivando a competição econômica. A competição é mais importante do que a instrução ou um maior acesso aos mercados, visto que ela é capaz de permitir o aumento do produto interno bruto de um país. Para reduzir barreiras à competição, é fundamental que nas definições políticas o bem-estar dos consumidores seja priorizado. 
É relevante destacar que o livro de Lewis tem como principal mérito alertar para duas questões que limitam a produtividade nacional: a informalidade, no sentido do não cumprimento de obrigações fiscais, sociais e face às normas de mercado, por parte de múltiplos agentes econômicos, e a burocracia licenciamento, ordenamento do território, prestação de serviços públicos. O somatório da consistência do método utilizado na pesquisa do instituto global de McKinsey e a longa experiência de Lewis com política econômica colocam o poder da produtividade como um tema relevante na economia global, sinalizando que o tema estará presente no debate político e econômico nos próximos anos no mundo.

Essas constatações tornam o livro de Lewis uma leitura obrigatória e uma fonte de estímulo para os governantes, políticos e empresários brasileiros, bem como para aqueles que se preocupam em aprofundar seus conhecimentos sobre política econômica e a importância da produtividade como fator de desenvolvimento socioeconômico do país. Em particular, os pesquisadores e estudantes dos cursos de graduação e pós-graduação em Economia, Administração, Contabilidade e Ciências Políticas.

\section{ReferênCIA Bibliográfica}

MATIAS-PEREIRA, J.

Ciência e Tecnologia e Desenvolvimento, Brasília, DF: PPGA/UnB. 2004. 